\title{
RUSSIA-GRECO COOPERATION: COMBATTING CORRUPTION IN THE FIELD OF STATE AND MUNICIPAL SERVICE
}

\author{
Irina P. Chikireva* \\ Galina A. Nelaeva **
}

\begin{abstract}
This article examines Russia-GRECO (Group of States against Corruption) cooperation in the field of anti-corruption policies by looking at the case of regulating state and municipal service. By looking at Recommendations and Evaluation Reports, the article seeks to explore the impact of GRECO on domestic norms in Russia. The question of disciplinary liability is examined further as one of the contentious points in Russia-GRECO interaction. While there is extensive literature on corruption in Russia and post-Soviet states, research on Russia's interaction with international organizations in this area is scarce. We hope to contribute to the existing research on international cooperation in the global fight against corruption, and to literature on states' interaction with (regional) international organizations with a view of post-Communist context. The article concludes that even if progress in the field of anti-corruption struggle has been slow, certain achievements must be noted, namely Russian anti-corruption laws and their implementation.
\end{abstract}

\section{INTRODUCTION}

The question of the impact of international law on domestic law is hardly a new topic for international law scholars. Much research has been done on the question of Russia's application and interpretation of international law. ${ }^{1}$ In this

\footnotetext{
Associate professor at Institute of state and law, Tyumen state university; chikireva777@ mail.ru

** Associate Professor at Institute of history and political science, Tyumen state university; g.a.nelaeva@utmn.ru

1 Marochkin, S. On the Recent Development of International Law: Some Russian Perspectives, Chinese Journal of International Law, Vol. 8 (3) 2009, p. 695-714.
} 
article we attempt to explore Russia's cooperation with the Council of Europe in the field of anti-corruption measures in the context of Russia's participation in GRECO, a topic that has not been sufficiently addressed in literature. While it is undeniable that Russia's interaction with the Council of Europe has been rather difficult, in the field of anti-corruption cooperation Russia has demonstrated a degree of success, albeit moderate, by accepting GRECO's recommendations and coordinating its domestic laws with European standards. Looking at the specific case of regulation of the state civil and municipal service, we seek to demonstrate that in Russia, although much remains to be done, some progress has been achieved with the adoption of the Federal Law 'On Combating Corruption', 'On State Civil Service' and 'On Municipal Service' and amendments to the Labor Code and the Criminal Code.

Anti-corruption measures were declared a priority with a new anti-corruption plan adopted in April 2016, and represent an important part of domestic policy-making. Corruption was often raised in visa liberalization talks between Russia and the European Union, when the latter required from Russia the adoption of measures aimed at regulating document security, migration, public security and anti-corruption, and human rights (related to the freedom of movement). ${ }^{2}$ The 2014 events resulted in the sanctions war and normative clashes with European countries and the United States and stalled the visa liberalization process. Europe, however, remains an important part of Russia's foreign policy. Thus, Russia cannot afford to step out of the anti-corruption regime and adopt a confrontationist stance against the Council of Europe in this field. Even if progress is rather slow (only 3\% of Russian respondents polled in 2013 believed that corruption decreased a lot (as compared to 37\% who thought that it increased a lot), ${ }^{3}$ the anti-corruption measures will continue to be translated into domestic law, as the example with state and municipal employees which we consider below, shows.

\section{INTERNATIONAL AND REGIONAL DIMENSIONS OF THE ANTI-CORRUPTION STRUGGLE: TOWARDS AN ANTI-CORRUPTION REGIME?}

Corruption, an age-old phenomenon, has been on the international agenda for decades. Hazardous effects of corruption have been mentioned in the recent

First Commission report on the implementation by Russia of the Common Steps for visa free-regime with the EU (18 December 2013), EU Press Release. Brussels, <http://europa.eu/ rapid/press-release_IP-13-1295_en.htm>, last accessed on 04/04/2017.

Global Corruption Barometer. Transparency International (2013), <http://www.transparency.org/gcb2013/country/?country=russia>, last accessed on 03/04/2017. 
study by the European Parliament, where it was estimated that, 'the lack of EUwide action against organized crime and corruption costs the EU at least $€ 71$ billion each year'. ${ }^{4}$ The growth of international treaties relating to corruption took place in the 1990s and was largely attributed to the end of the Cold War when in the global context of debates over democratization trajectories it was no longer politically wise to support corrupt regimes. Anti-corruption struggle was also spurred by the necessity to regulate international trade, hindered by corrupt practices of states and/or multinational corporations. While Foreign Corrupt Practices Act (FCPA) adopted in the United States in 1977 because of a number of scandals involving business practices of multinationals became an example of 'modern, more global battle', 5 a truly global regime started to form a few decades later in the framework of multilateral cooperation within international institutions. Thus, a number of international and regional treaties emerged, among which were the OECD Convention on Combating Bribery of Foreign Public Officials in International Business Transactions (1997, entered into force in 1999), Council of Europe Criminal Convention on Corruption (1998, entered into force in 2002) and Additional Protocol (2003, entered into force in 2005), and Civil Law Convention on Corruption (1999, entered into force in 2003). The United Nations Convention against corruption (UNCAC) (2003, entered into force in 2005) became the first universal anti-corruption instrument, ratified by 177 states. The UNCAC regulates international cooperation in five main areas: prevention, criminalization and law enforcement measures, international cooperation, asset recovery, and technical assistance and information exchange. Corruption was conceptualized not only as a threat to institution-building, ethical values, democracy and justice (UNCAC Preamble) but also as an impediment to sustainable development, a facilitating factor in the spread of wildlife trafficking and terrorism (Global fight...2015). Among the regional initiatives there are Inter-American Convention Against Corruption (IACAC), and African Union Convention on Preventing and Combating Corruption.

International financial institutions also took part in this effort against 'the cancer of corruption', in the words of James D. Wolfensohn, World Bank President (1995-2005), who, in his Annual Address of 1996 stressed that, 'the Bank Group will not tolerate corruption in the programs that we support; and we are taking steps to ensure that our own activities continue to meet the highest

\footnotetext{
4 Maurice, E., Corruption costs EU €71bn a year, EU Observer (23 March 2016), <https:// euobserver.com/justice/132784>, last accessed 04/04/2017.

5 Bonime-Blanc, A. The Fight Against Corruption Goes Global, Foreign Affairs (February 14, 2012), <https://www.foreignaffairs.com/articles/2012-02-14/fight-against-corruption-goesglobal>, last accessed 04/04/2017.
} 
standards of probity'. ${ }^{6}$ World Bank maintains its Worldwide Governance Indicators, where one of the six dimensions of governance is control of corruption (WGI Project). IMF also framed its anti-corruption stance in terms of 'good governance' and linked the provision of loans to anti-corruption policies. ${ }^{7}$ It encourages states to disseminate information about economics and finance among the public through its Special Data Dissemination Standard.

Regional European initiatives, apart from the CoE Criminal and Civil Law Conventions, include EU anti-corruption legislation, such as the Convention on the protection of the European Communities' Financial Interests and European Union Convention against Corruption Involving Officials. Even if the European Union has not been as visible as the Council of Europe in this anti-corruption struggle, it certainly played an important role in the context of transition of Central and Eastern European states from post-Communism to democracy. On the global scale, if we speak about Russia, Corruption Perception Index (CPI) by Transparency International shows that Russia falls into "the largest group of countries, encompassing 5.2 billion people or $72 \%$ of the world", alongside with China, India, many South-East Asian states, Africa, and some states of Latin America. ${ }^{8}$ While these figures certainly raise questions as to the effectiveness of this regime and its global implications, it goes without saying that the spread of international norms and prohibitions has an impact on domestic law-making, as the case of Russia shows.

\section{CONCEPTUALIZING CORRUPTION: RUSSIA'S POST- COMMUNIST EXPERIENCE}

There is extensive literature that explores Russia and other post-Communist states in their effort to combat corruption. ${ }^{9}$ Although more than twenty years have passed since the collapse of communism, researchers note very slow progress of states in this field. Russia, with its rather uneven process of transition and tempestuous relations with Europe has been a much more

\footnotetext{
6 Annual Meetings Address by James D. Wolfensohn, President of the World Bank, (1 October 1996). <http://web.worldbank.org/WBSITE/EXTERNAL/EXTABOUTUS/ORGANIZATION/EXTPRESIDENT/EXTPASTPRESIDENTS/PRESIDENTEXTERNAL/0,,contentMDK:20025269 menuPK:232083 pagePK:159837 piPK:159808 theSitePK:227585,00. html $>$, last accessed 03/04/2017.

7 The IMF and Good Governance. Factsheet (14 March 2016), <http://www.imf.org/external/np/exr/facts/gov.htm>, last accessed 04/04/2017.

8 Warf, B., Global Geographies of Corruption, GeoJournal Vol. 1 (13), 04 June 2015.

9 Holmes, L., Corruption and the Crisis of the Post-Communist State, Crime, Law \& Social Change, Vo. 27, 1997, p. 275-297.
} 
difficult participant in the global anti-corruption struggle. Especially this is true in the context of Russia's relations with the Council of Europe, which it joined in 1996. Why Russia has been a latecomer in this global anti-corruption regime is subject to further research, but several historical points deserve to be mentioned: in Soviet Russia corruption was conceptualized as a bourgeois phenomenon. The Criminal Code of RSFSR (1922), however, envisaged criminal liability for bribery. ${ }^{10}$ During the political purges of the 1930 s and during WWII, corruption-related offenses were severely punished and largely silenced, which was also true for the time of Kruschev's 'thaw' and Brezhnev's 'stagnation', since corruption cast a negative light on the Communist Party and the Soviet leadership. It was in the late 1980s-early 1990s, in the aftermath of perestroika, the dissolution of the USSR, and large-scale privatization, when a new kleptocratic oligarchy stratum was formed, that corruption clearly became not only a country-wide evil, but a threat to the very existence of the state and the society. ${ }^{11}$ Researchers point out that corruption has generated a multiplicity of hazardous effects in various spheres of life, from banking sector, ${ }^{12}$ to law enforcement, ${ }^{13}$ and education. ${ }^{14}$ While the phenomenon of corrupt elites is certainly not typical just for Russia, in Russia the Gini coefficient (that ranges from 0 when almost everybody in the country has similar income to 1 with serious income inequalities) comprised 0.45 , much higher than in other CEE states and comparable to the Third World countries. ${ }^{15}$

Post-Soviet Russia has become a party to several anti-corruption treaties. An-

10 Polyakov, M. M., Protivodejstvie korrupcii sovetskimi organami prokuratury v sisteme gosudarstvennoj vlasti, Izvestija TulGU, Vol. 1 (2) Jekonomicheskie i juridicheskie nauki, 2013, ['Counteracting Corruption by Prosecutor's Offices in the System of State Power', Tula State University Herald: Economic and Legal Studies], <http://cyberleninka.ru/article/n/protivodeystvie-korruptsii-sovetskimi-organami-prokuratury-v-sisteme-gosudarstvennoy-vlasti>, last accessed 04/04/2017.

11 Hillstrom, B. Effects of Corruption on Democracies in Asia, Latin America, and Russia, The Woodrow Wilson Center Report, Vol. 8 (3) 2006, p. 29-30.

12 Weill, L., How Corruption Affects Bank Lending in Russia, Economic Systems Vol. 35 (2), 2011. WGI Project, <http://info.worldbank.org/governance/wgi/index.aspx\#home>, last accessed 04/04/2017.

13 Gerber, T., Mendelson, S. E., Public Experiences of Police Violence and Corruption in Contemporary Russia: a Case of Predatory Policing?, Law and Society Review Vol. 42 (1), 2008, pp. 1-44.

14 Nemtsova, A. In Russia, Corruption Plagues the Higher-Education System, Chronicle of Higher Education Vol. 54 (24), 2008, <http://eric.ed.gov/?id=EJ788930>, last accessed 04/04/2017.

15 Berend, I.T., Bugaric, B. Unfinished Europe: Transition from Communism to Democracy in Central and Eastern Europe, Journal of Contemporary History, Vol. 50 (4), 2015, p. 768-785, at 72 . 
ti-corruption efforts were speeded up after Russia signed (2003) and ratified (2006) the United Nation Convention against Corruption, followed by $\mathrm{CoE}$ Criminal Convention on Corruption (2007) and OECD Convention on Combating Bribery of Foreign Public Officials in International Business Transactions (signed on in February 2012 and ratified in April the same year).

The CoE Criminal Convention on Corruption, while adhering to a more restrictive definition of corruption than the UNCAC, emphasizes that "corruption threatens the rule of law, democracy and human rights, undermines good governance, fairness and social justice, distorts competition, hinders economic development and endangers the stability of democratic institutions and the moral foundations of society' (Preamble). GRECO (a group of states against corruption) was set up in 1999 and included Council of Europe member states and the USA. Russia made a decision to join this group in February 2007 by declaring its commitment to create 'a common European legal space to protect individuals from modern-day challenges'. ${ }^{16}$ It also signed and ratified the Criminal Convention on Corruption without reservations and agreed to participate in GRECO's activities, which include regularly evaluation process. Russia also cooperated with the CoE in the framework of RUCOLA 2, a project aimed at developing anti-corruption legislation, which involved the State Duma, the lower house of the Russian Parliament. Why Russia chose to join this group is subject to debate but it is important to bear in mind that anti-corruption strategies remain an important point in Russia's interaction with European countries.

Afterjoining GRECO,RussiaadopteditsFederalLaw 'OnCombatingCorruption' (25 December 2008) N 273-FZ, which has become the core law in the overall anti-corruption struggle. This law has been amended twelve times since then, and as a consequence, led to the tougher criminal, administrative and disciplinary liability for corruption-related offenses. What was also introduced was the obligation of the Prosecutor's Office on the federal level and in the subjects of the federation to make their monitoring reports on the implementation of the Federal Law pubic, to raise awareness of the problem.

According to Article 1 of the Federal Law 'On Combating Corruption', corruption is conceptualized as 'abuse of official position, giving a bribe, receiving a bribe, abuse of powers, a commercial graft or any other illegal use of his/her official position by an individual contrary to the legal interests of the society and state in order to receive profit or benefit in the form of money, valu-

16 Foreign Minister Sergey Lavrov's Statement, Council of Europe Press Release (1 February 2007), <https://www.coe.int/t/dghl/monitoring/greco/news/News2007/News(20070201) PressReleaseRussia44thmember_en.asp>, last accessed 04/04/2017. 
ables, other property and services of property nature, other property rights for himself/herself or for the third persons or illegal presenting of such advantage to the above mentioned person by other individuals as well as committing the above mentioned actions on behalf or in the interests of a legal entity.' In the same Article it is specified that anti-corruption refers to the activities of federal authorities, authorities of the subjects of the Federation, local authorities, civil society, individuals and legal persons, aimed at:

1. preventing corruption, including the identification and subsequent elimination of the causes of corruption (corruption prevention);

2. identifying, preventing, suppressing, detecting and investigating corruption offenses (anti-corruption);

3. minimizing and (or) liquidating the consequences of corruption offenses.

On the basis of Article 3 of the Federal Law «On Combating Corruption» fight against corruption in the Russian Federation is based on the following principles:

1. recognition, promotion and protection of fundamental rights and freedoms of man and citizen;

2. legality;

3. publicity and openness of activities of state bodies and local self-government;

4. the inevitability of punishment for corruption offenses;

5. the use of political, institutional, outreach, social, economic, legal, special and other measures;

6. priority to the preventive measures;

7. cooperation between the state and civil society institutions, international organizations and individuals.

While this definition has been criticized by GRECO as will be noted below, it remains the most detailed definition so far adopted in post-Soviet Russia.

\section{RUSSIA-GRECO INTERACTION IN THE FIELD OF ANTI- CORRUPTION POLICIES: REGULATING STATE AND MUNICIPAL SERVICE}

According to the Transparency International Global Corruption Barometer (2013), the respondents in Russia named public officials and civil servants as corrupt/extremely corrupt (92\%), followed by the police (89\%), the judiciary 
$(84 \%)$ and the parliament and legislature (83\%). ${ }^{17}$ Thus, anti-corruption measures, especially in the field of regulating civil service, remain an important dimension of domestic anti-corruption policy.

Examining the area of anti-corruption measures in the field of civil/municipal service is important also because state and municipal employment represents one of the most contentious issues in Russia-GRECO relations.

Several contentious points must be mentioned in Russia-GRECO relations. One of such points is the various forms of liability envisaged for corruption. GRE$\mathrm{CO}$ has expressed its concern that the existence of parallel criminal and administrative systems afforded opportunities for manipulation, for example, the escape from the justice process'. ${ }^{18}$ GRECO was concerned that article 13 of the Law 'On Combating Corruption' remained unchanged: it provides that persons who commit crimes of corruption can be subjected not only criminal, but also administrative or civil liability procedure for corruption. From this it was concluded that the general definition of corruption contained in the Law № 273-FZ, might not play a decisive role in the choice of the criminal or administrative proceedings, and even though in theory the criminal proceedings were given priority, the existence of two parallel procedures regarding crimes of corruption provided opportunities for manipulation. GRECO recommended administrative governance reforms aimed at fighting corruption, which would apply to a large number of civil servants, and not only to a narrow category of public servants.

GRECO recommended reviewing the system of administrative procedures and criminal proceedings with a view to ensure that corruption cases were treated as criminal offenses. In particular, it was proposed that a new anti-corruption principle was added to enable a clear distinction between administrative and criminal offenses. The proposal suggested that the provision which would make corruption a criminal offense is added. The authorities claim that the introduction of this new principle would facilitate a more clear distinction between administrative and criminal liability for crimes of corruption and would ensure that the perpetrators of corruption were prosecuted primarily on the basis of the Criminal Code. This proposal was approved by the Ministry of Justice in late 2011, and sent to the State Duma by the General Prosecutor's Office. However, the necessary changes to the law 'On Combating Corruption' have not been introduced yet.

17 Global Corruption Barometer. 2013. <https://www.transparency.org/gcb2013>, last accessed 06/06/2017.

18 GRECO Third Evaluation Report (22 March 2012), <http://www.coe.int/t/dghl/monitoring/greco/evaluations/round3/GrecoEval3(2011)6_RussianFed_One_EN.pdf>, last accessed 04/04/2017. 
Thus, GRECO recommends treating corruption-related offenses first and foremost as criminal offenses. Russia, however, believes that, the administrative procedure applies only in those cases where it is impossible to apply the criminal one. Even if disciplinary liability does not rule out other forms of liability, including administrative and criminal one, necessary changes in domestic laws have not yet been made.

In its Addendum to the Compliance Report on Russia from 3-7 December 2012 GRECO emphasizes that recommendations have been 'partly implemented' (Addendum, 2012, 5). In the same document GRECO adds, however, that "a number of legislative reforms remain to be completed" (Addendum, 2013 , 132), in particular, in the field of planned amendments to the law "On Combating Corruption" (to ensure that acts of corruption are to be considered, as a main rule, as criminal offenses), amendments to the Russian Criminal Code, which should include provisions to enable confiscation of proceeds from all corruption offenses and to the Civil Code (prohibiting gifs within the public administration).

A very sensitive issue is listed further in the report: the question of public officials' immunity (for corruption, inter alia). Moreover, it has also been recommended to strengthen judicial independence and control over public administration, the reporting of corruption and protection of whistle-blowers. 'The implementation and monitoring of impact of such measures should continue to feature prominently in the national anti-corruption action plans, including by ensuring input by civil society'. ${ }^{\prime}$

In 2014 during its $64^{\text {th }}$ meeting in Strasbourg, GRECO adopted its Third Evaluation Report. It is noted that the big number of recommendations have been complied with by the Russian Federation either fully or partially. Two major topics were covered by the Evaluation Report: Incriminations and Transparency of Party Funding (Third Evaluation Report, 2012). Based on GRECO recommendations and evaluation report Russia developed draft laws and introduced amendments into existing laws regulating corruption, in particular, to the Federal Law 'On Combating Corruption'.

In accordance with GRECO recommendations of 23 December 2010, the Presidium of the Council for Countering Corruption adopted Model Code of Ethics and Professional Conduct for Public Officials of the Russian Federation, which became the basis for elaborating similar codes for state and municipal

19 Addendum to the Compliance Report on the Russian Federation. Joint First and Second Evaluation Round. Greco RC-I/II (2010) 2E (15 March 2013), <https://www.coe.int/t/dghl/ monitoring/greco/evaluations/round2/GrecoRC1\&2(2010)2_RussianFederation_EN.pdf>, at 132, last accessed 04/04/2017. 
employees. At the level of the subjects of the Federation, Presidential Decree 'On the National Ant-Corruption Plan 2014-2015' (11 April 2014) regulates compliance of legislative acts and executive orders in the anti-corruption field with the National Anti-corruption Strategy, increasing public awareness and stimulating research.

According to the General Prosecutor's Office, in the period of nine months of 2014 they received more than 400 complaints. ${ }^{20}$ Russians are increasingly using on-line complaint procedure, which ensures immediate delivery rather than postal services which take quite some time. Often complaints relate to violations of criminal procedure, and pre-trial investigation of corruption. All complaints were examined and measures were taken, according to the official web-site of the Office of the Prosecutor-General.

Prosecutor's offices in the subjects of the Federation are also obliged to conduct monitoring and reporting. Violations of anti-corruption laws entail criminal, administrative and disciplinary liability. For example, according to the interim report of Prosecutor's office of Sverdlovsk region, in the period of 9 months of 2015 the main efforts were directed at detection and suppression of violations of laws regulating state and municipal service, in the field regulating exploitation of state and municipal property, in the field of budgetary affairs, health services, housing and communal services, and other fields where corruption offenses are most common. Thus, in the period of 9 months of 2015 the Prosecutor's Office reported 6123 violations, 627 illegal legislative acts which generated 636 prosecutorial protests (573 acts were amended or annulled as a result), 329 lawsuits were directed to the court, 1129 applications were initiated and on the basis of them, 1017 public officials were subjected to disciplinary liability, 140 warning were issues, 457 were subjected to administrative liability and 57 criminal lawsuits began in accordance with Article 37 of Criminal Procedure Code. ${ }^{21}$

Anti-corruption legislation on the level of the subjects of the Federation has been extensive as well. For example, in Tyumen Region, a range of legislative anti-corruption laws applies: there is a regional anti-corruption plan and a Model anti-corruption plan for municipal entities, adopted by the executive decree of Tyumen Region government N 1244 on 23 April 2012, Tyumen Region Law of 25 February 2009 N 6 "On Combating Corruption in Tyumen Region”, Executive Decree "On Anti-Corruption Expertise of draft laws and other documents in Tyumen Region with the purpose of identifying clauses that might facilitate condition for corruption" (Official portal of Tyumen region). Similar

\footnotetext{
20 Official Web-site of the General Prosecutor's Office, http://genproc.gov.ru/smi/news/genproc/news-464097, last accessed 05/04/2017.

21 Official Website of Sverdlovsk Region Prosecutor's Office, <http://prokurat-so.ru/main. php?id=1741>, last accessed 05/04/2017.
} 
laws have been adopted in other subjects of the Federation, for example, 'On Combating Corruption in Sverdlovsk Region' (2009), 'On Combating Corruption in Chelyabinsk Region’ (2009). Regional laws appeared after the Federal Law on Combating Corruption (2008) was adopted, thus, before Russia joined GRECO, none existed on the regional level.

Thus, even if progress has been slow, GRECO recommendations find their way into Russian domestic legal system and are implemented in practice.

\section{THE QUESTION OF DISCIPLINARY LIABILITY OF STATE AND MUNICIPAL EMPLOYEES}

Disciplinary liability of state and municipal employees has been a contentious point in Russia-GRECO relations. We would like to note that it should first of all be regarded as a preventive measure in the overall anti-corruption strategy, and not as an exclusive form of liability. Several problematic aspects deserve clarification, however. To begin with, the question of disciplinary liability of state civil and municipal employees entails the necessity of coordinating anti-corruption responsibilities of municipal employees as defined by Federal law 'On Combating Corruption' and the Federal Law 'On Municipal Service in the Russian Federation' and 'On State Civil Service', as well as the necessity to specify the peculiarities of 'moral reprimand' as applied to state and municipal employees for violating Model Code on Ethics and Professional Conduct.

As Article 192 of the Labor Code states, a disciplinary measure can be applied if all procedural requirements are met. For disciplinary liability to apply, the employee should have committed a disciplinary offense: non-performance or inadequate performance of his/her duties. There are three forms of disciplinary measures: a) notice; b) reprimand; c) dismissal. When choosing a disciplinary measure, the procedural issues must be respected, such as the employee's written statement clarifying the reasons for his/her behavior. A disciplinary measure must be applied no later than one month since the date when the offense was recorded. One disciplinary offense must entail one disciplinary measure.

Article 57 of the Federal Law 'On the State Civil Service' in addition to the notice, reprimand and dismissal for a disciplinary offense provides for the possibility of imposing on a state civil servant another form of disciplinary liability in the form of a warning. This warning means that the official does not fully meet the requirements of his/her position.

Recommendation xx by GRECO suggests 'to review the current measures designed to prevent conflicts of interest in order to clarify their scope of application in respect of public officials and their relatives, to remedy the short- 
comings identified and to ensure that the necessary measures are fully implemented in practice'. ${ }^{22}$ This recommendation was listed as partly implemented. Several problems persist, namely, weak control mechanisms. According to the Russian authorities' report, in the Federal Law 'On amendments made in some legislative acts of the Russian Federation in connection with promoting state management in the area of combating corruption' (N329-FZ) of 21 November 2011, 'loss of trust' was introduced among the grounds for dismissal of a state or municipal employee if $\mathrm{s} /$ he is not able to take preventive action against conflict of interest (including those which arise in respect of his/her subordinates). In the Anti-Corruption Plan for 2012-2013 it was mentioned that the Presidium of the Council for Counteracting Corruption and the federal state bodies had the competence to detect conflicts of interest. The procedure for settling conflicts of interests was outlined in the Presidential Decree No. 233 (25 February 2011). Presidential Decree 'On Commissions for controlling compliance with the requirements of service conduct by federal public officials and the settling of conflicts of interest' (No. 821) (1 July 2010) enabled the establishment of special commissions, and GRECO notes that, 'such commissions have been established by all federal public authorities and 3416 commissions have been set up by the authorities' territorial bodies,' and 2788 public officials were subjected to disciplinary liability in 2010-2011 (4.4 times increase) (Addendum, 2013, 94). Ministry of Labor and Social Protection was charged with monitoring the commissions' activities.

According to Article 27.1 of the Federal Law 'On Municipal Service in the Russian Federation', municipal employees may be subject to disciplinary liability to violating anti-corruption laws. Such can be the case when there are instances of violating laws regulating conflict of interest (Article 14.1), as well as non-disclosure of information relating to income, expenses, property and non-material responsibilities (Article 15).

Article 59.2 of the Federal Law 'On State Civil Service in the Russian Federation' mentions broader grounds for dismissal of state civil employees. In the field of state civil service, the Federal Law stipulates (Article 19) that civil employees may be dismissed in cases of failure of a civil servant, being party to a conflict of interest, to take preventive measures or resolve a conflict of interest; failure to submit information on his/her income and property-related obligations, participation of a state civil employee in management of a commercial organization, except in cases stipulated by Federal Law; entrepreneur-

22 Addendum to the Compliance Report on the Russian Federation. Joint First and Second Evaluation Round. Greco RC-I/II (2010) 2E (15 March 2013), <https://www.coe.int/t/dghl/ monitoring/greco/evaluations/round2/GrecoRC1\&2(2010)2_RussianFederation_EN.pdf>, at 91, last accessed 05/04/2017. 
ial activities of a state civil employee; participation of a state civil employee in management/board of governance of non-governmental organizations (unless stipulated by an international treaty or domestic law). Representative of an employer would be subject for dismissal if $\mathrm{s} /$ he was aware of the conflict of interest but failed to take measures to prevent or solve it.

The Law 'On Combating Corruption' lists several main responsibilities of state/ municipal employees to comply with anti-corruption laws: Article 8 lists the obligation to submit the information about their income, property and property obligations, as well as the income, property and property obligations of their spouse and underage children, Article 9 talks about the liability to report to the employer/the Prosecutor's office or other state institutions of attempts to induce him/her to commit corruption offenses, Article 11 - the obligation to take measures to prevent any possibility of a conflict of interests.

GRECO recommended developing and publishing the model code of conduct / ethics for civil servants / officials, including state servants, which could be adapted to the specific needs of the various sectors of the state apparatus. On 23 December 2010, 'The Model Code of Ethics and Professional Conduct of State Employees of the Russian Federation and the Municipal Employees' (hereinafter the Model Code) was adopted by the Presidium of the Anti-Corruption Council. The Code is based on universally recognized principles and contains general rules of ethics and conduct in accordance with the anti-corruption law, and it must be followed by the officials of the Russian Federation, as well as citizens serving in the armed forces and law enforcement agencies. In the process of drafting the code, similar codes of the conduct of judges, law enforcement officers, auditors, lawyers / attorneys were taken into account. The Code is aimed at regulating the standards of professional conduct and ethics, at the provision of assistance to the officials in the observance of these rules, and at informing the public about the behavior which is to be expected from officials. Following the adoption of the Model Code, similar codes were drafted in 55 federal bodies.

In paragraphs 26-27 of the Model Code it is noted that a state/municipal employee should refrain from:

1. any kind of statements and actions which are discriminatory on the grounds of sex, age, race, nationality, language, nationality, social status, wealth or marital status, political or religious preferences;

2. rudeness, contemptuous behavior, arrogant, prejudiced comments, making illegal, unfair accusations;

3. threats, abusive language or remarks, actions that prevent normal communication or provoke illegal behavior; 
4. smoking during business meetings, interviews, other official meetings with the citizens.

\section{CONCLUSION}

The system of legal regulation of anti-corruption measures is being formed in Russia with a significant impact of GRECO recommendations. Unresolved issues, related, first of all, to the insistence by GRECO that corruption offenses should be treated as criminal offenses, and the question of immunity, as well as conflict-of-interest prevention, persist. However, various forms of liability currently envisaged in Russia (administrative and civil) do not exclude the possibility of criminal prosecution. International norms and the GRECO recommendations in particular, have a strong influence on domestic law-making and subsequent implementation.

As far as practical recommendations are concerned, we believe it is important to introduce changes to Articles 27 and 27.1 of the law 'On Municipal Service in the Russian Federation' and Articles 57 and 59.2 of the law 'On State Civil Service in the Russian Federation', which would enable to unify the types of disciplinary penalties and the grounds for dismissal of municipal and state employees for corruption-related offenses. It also is important to address such problematic issues as the legal status of moral reprimand and legal consequences of its application.

As Berend and Bugaric correctly note, for the process of transition to work, there should be not only free market, enterprise and foreign direct investment, but also social-behavioral-moral transformation. ${ }^{23}$ This is especially relevant in the context of corruption, since in CEE states, including Russia, corruption is frequently perceived by the business elite and the public at large as a way to solve problems. Existence of various shadow networks which function alongside state institutions, undermines state security, ${ }^{24}$ and leads to the lack of trust on the part of the population in the capacities of the state. Transition, however, cannot come overnight. Even if implementation of anti-corruption measures appears to be uneven, the modest achievements of the past years offer reasons to hope.

\footnotetext{
23 Berend, I.T., Bugaric, B. Unfinished Europe: Transition from Communism to Democracy in Central and Eastern Europe, Journal of Contemporary History, Vol. 50 (4), 2015, p.768-785, at 785 .

24 Nechaev, M. A. O roli gosudarstva v protivodejstvii korrupcii: pravovye aspekty, Juridicheskaja nauka, 1, 2013. ['On the Role of the State in Combating Corruption: Legal Aspects', Legal Studies], <cyberleninka.ru/article/n/o-roli-gosudarstva-v-protivodeystvii-korruptsiipravovye-aspekty $>$, last accessed 14.05.2017.
} 


\section{LITERATURE:}

1. Addendum to the Compliance Report on the Russian Federation. Joint First and Second Evaluation Round. Greco RC-I/II (2010) 2E (15 March 2013), <https:// www.coe.int/t/dghl/monitoring/greco/evaluations/round2/GrecoRC1\&2(2010)2_ RussianFederation_EN.pdf>, at 132, last accessed 04/04/2017.

2. Addendum to the Compliance Report on the Russian Federation. Joint First and Second Evaluation Round. Greco RC-I/II (2010) 2E (15 March 2013), <https:// www.coe.int/t/dghl/monitoring/greco/evaluations/round2/GrecoRC1\&2(2010)2_ RussianFederation_EN.pdf $>$, at 91, last accessed 05/04/2017.

3. Annual Meetings Address by James D. Wolfensohn, President of the World Bank, (1 October 1996).<http://web.worldbank.org/WBSITE/EXTERNAL/ EXTABOUTUS/ORGANIZATION/EXTPRESIDENT/EXTPASTPRES IDENTS/PRESIDENTEXTERNAL/0, contentMDK:20025269 menuP$\mathrm{K}: 232083 \sim$ pagePK:159837 piPK:159808 theSitePK:227585,00.html>, last accessed 03/04/2017.

4. Berend, I.T., Bugaric, B. Unfinished Europe: Transition from Communism to Democracy in Central and Eastern Europe, Journal of Contemporary History, Vol. 50 (4), 2015, p.768-785.

5. Bonime-Blanc, A. The Fight Against Corruption Goes Global, Foreign Affairs (February 14, 2012), <https://www.foreignaffairs.com/articles/2012-02-14/fightagainst-corruption-goes-global>, last accessed 04/04/2017.

6. First Commission report on the implementation by Russia of the Common Steps for visa free-regime with the EU (18 December 2013), EU Press Release. Brussels, <http://europa.eu/rapid/press-release_IP-13-1295_en.htm>, last accessed on 04/04/2017.

7. Foreign Minister Sergey Lavrov's Statement, Council of Europe Press Release (1 February 2007), <https://www.coe.int/t/dghl/monitoring/greco/news/News2007/ News(20070201)PressReleaseRussia44thmember_en.asp $>$, last accessed 04/04/2017.

8. Gerber, T., Mendelson, S. E., Public Experiences of Police Violence and Corruption in Contemporary Russia: a Case of Predatory Policing?, Law and Society Review Vol. 42 (1), 2008, pp. 1-44.

9. Global Corruption Barometer. Transparency International (2013), <http://www. transparency.org/gcb2013/country/?country=russia>, last accessed on 03/04/2017.

10. GRECO Third Evaluation Report (22 March 2012), <http://www.coe.int/t/dghl/ monitoring/greco/evaluations/round3/GrecoEval3(2011)6_RussianFed_One_ EN.pdf $>$, last accessed 04/04/2017.

11. Hillstrom, B. Effects of Corruption on Democracies in Asia, Latin America, and Russia, The Woodrow Wilson Center Report, Vol. 8 (3) 2006, p. 29-30. 
12. Holmes, L., Corruption and the Crisis of the Post-Communist State, Crime, Law \& Social Change, Vol. 27, 1997, p. 275-297.

13. Marochkin, S. On the Recent Development of International Law: Some Russian Perspectives, Chinese Journal of International Law, Vol. 8 (3) 2009, p. 695-714.

14. Maurice, E., Corruption costs EU $€ 71$ bn a year, EU Observer (23 March 2016), $<$ https://euobserver.com/justice/132784>, last accessed 04/04/2017.

15. Nechaev, M.A. O roli gosudarstva v protivodejstvii korrupcii: pravovye aspekty, Juridicheskaja nauka, 1, 2013. ['On the Role of the State in Combating Corruption: Legal Aspects', Legal Studies], <cyberleninka.ru/article/n/o-roli-gosudarstva-v-protivodeystvii-korruptsii-pravovye-aspekty>, last accessed 14/05/2017.

16. Nemtsova, A. In Russia, Corruption Plagues the Higher-Education System, Chronicle of Higher Education Vol. 54 (24), 2008, <http://eric.ed.gov/?id=EJ788930>, last accessed 04/04/2017.

17. Official Website of Sverdlovsk Region Prosecutor's Office, <http://prokurat-so.ru/ main.php?id=1741>, last accessed 05/04/2017.

18. Official Web-site of the General Prosecutor's Office, http:/genproc.gov.ru/smi/ news/genproc/news-464097, last accessed 05/04/2017.

19. Polyakov, M. M., Protivodejstvie korrupcii sovetskimi organami prokuratury v sisteme gosudarstvennoj vlasti, Izvestija TulGU, Vol. 1 (2) Jekonomicheskie i juridicheskie nauki, 2013, ['Counteracting Corruption by Prosecutor's Offices in the System of State Power', Tula State University Herald: Economic and Legal Studies], <http://cyberleninka.ru/article/n/protivodeystvie-korruptsii-sovetskimi-organami-prokuratury-v-sisteme-gosudarstvennoy-vlasti>, last accessed 04/04/2017.

20. The IMF and Good Governance. Factsheet (14 March 2016), <http://www.imf.org/ external/np/exr/facts/gov.htm>, last accessed 04/04/2017.

21. Warf, B., Global Geographies of Corruption, GeoJournal Vol. 1 (13), 04 June 2015.

22. Weill, L., How Corruption Affects Bank Lending in Russia, Economic Systems Vol. 35 (2), 2011. WGI Project, <http://info.worldbank.org/governance/wgi/index. aspx\#home>, last accessed 04/04/2017. 